\title{
Calyptranthes grandifolia O.Berg (Myrtaceae) ethanolic extract inhibits TNF- $\alpha$ gene expression and cytokine release in vitro
}

\author{
GEÓRGIA MUCCILLO DEXHEIMER ${ }^{1}$, LUCIANA KNABBEN DE OLIVEIRA BECKER DELVING ${ }^{2}$, \\ HENRIQUE SULZBACH DE OLIVEIRA ${ }^{1}$, VANDERLEI BIOLCHI ${ }^{2}$, \\ MÁRCIA INÊS GOETTERT ${ }^{1}$ and ADRIANE POZZOBON ${ }^{2}$ \\ ${ }^{1}$ Biotechnology Program; ${ }^{2}$ Molecular Biology Laboratory and Medical School, \\ Univates, Lajeado, RS 95900-000, Brazil
}

Received June 28, 2016; Accepted January 20, 2017

DOI: $10.3892 / \mathrm{mmr} .2017 .6319$

\begin{abstract}
Anti-tumor therapies based on anti-inflammatory effects have been considered in cancer treatment. Survival, proliferation and, resultantly, invasion and metastasis of tumor cells are regulated by local inflammatory mediators. Primary inflammatory cytokines, such as tumor necrosis factor (TNF), are targets for anticancer therapy. Several anti-inflammatory agents isolated from natural products are becoming important chemopreventive and therapeutic agents for cancer. The present study aimed to investigate the expression of $\mathrm{TNF}-\alpha$, nuclear factor- $\kappa \mathrm{B}(\mathrm{NF}-\kappa \mathrm{B})$ and $\mathrm{p} 38 \alpha$ mitogen-activated protein kinase (p38 $\alpha$ ) genes, associated with proliferation and inflammation in the Caco-2 cell line treated with ethanolic and hexanic extracts of Calyptranthes grandifolia O.Berg (Myrtaceae). Caco-2 cells were cultured and treated with plant extract at different concentrations $(25,50,100$ and $200 \mu \mathrm{g} / \mathrm{ml})$ and stimulated with lipopolysaccharide (LPS). For gene expression, analysis was performed by total RNA extraction followed by synthesis of complementary DNA and analysis by quantitative polymerase chain reaction. The release of TNF- $\alpha$ cytokine was evaluated by ELISA in RAW 264.7 murine macrophages activated by LPS. Among the evaluated genes, there was a decrease in TNF- $\alpha$ expression at 100 and $200 \mu \mathrm{g} / \mathrm{ml}$ concentrations only with the ethanolic extract $(\mathrm{P}<0.025)$. The p38 $\alpha$ gene exhibited a tendency to increase expression only when treated with ethanolic extract and the NF- $\mathrm{NB}$ gene did not significantly differ compared with the positive control when treated with either analyzed extract. The inhibition of TNF- $\alpha$ cytokine in the RAW 264.7 cell line was significant $(\mathrm{P}<0.05)$ in ethanolic extract at $200 \mu \mathrm{g} / \mathrm{ml}$ compared with the positive control (LPS $1 \mu \mathrm{g} / \mathrm{ml}$ ). In conclusion, the ethanolic
\end{abstract}

Correspondence to: Ms Geórgia Muccillo Dexheimer, Biotechnology Program, Univates, 171 Avenida Avelino Tallini, Lajeado, RS 95900-000, Brazil

E-mail: georgiamuccillo@gmail.com

Key words: inflammation, cancer, gene expression, cytokine, Calyptranthes grandifolia extract may exhibit an anti-inflammatory activity by inhibiting TNF- $\alpha$. However, further studies are required to confirm its potential anti-inflammatory effects.

\section{Introduction}

Inflammation associated with cancer is a promising target for the development of anticancer therapies. Cytokines, chemokines and growth factors may have an important function in the interaction between tumor cells and infiltrating leukocytes from blood vessels. The existence of inflammatory components in the microenvironment of neoplastic tissues frequently leads to increased angiogenesis, resistance to hormones and inhibition of adaptive anti-tumor immunity. The survival, proliferation and subsequent invasion and metastasis of tumor cells is regulated by inflammatory mediators present at the tumor site (1).

Primary inflammatory cytokines, including interleukin-1 (IL-1) and tumor necrosis factor (TNF), expressed by leukocytes and tumor infiltrating cells, are targets for anticancer therapy. Anti-cytokine strategies against tumors have been investigated with TNF inhibitors in certain inflammatory diseases (2). Clinical trials with TNF- $\alpha$ antagonists, alone or combined with other therapies, have been performed in patients with cancer. In cases of advanced solid cancer, TNF- $\alpha$ antagonists were well tolerated and exhibited biological activity and partial response with renal carcinoma or stable disease $(3,4)$. Permanent activation of $N F-\kappa B$ contributes actively in tumorigenesis by promoting cell cycle progression and inhibiting apoptosis. NF- $\kappa \mathrm{B}$ is activated through TNF- $\alpha$, thus inhibition of this factor may support cancer therapies that target apoptosis $(5,6)$. Inhibition of $N F-\kappa B$ is associated with apoptosis and reduced cell growth, and this inhibition may be beneficial in the treatment of cancer (7). The p38 $\alpha$ mitogen-activated protein kinase (p38 $\alpha$ MAPK) may have tumor suppressor activity through regulation of the p53 gene, which interferes with cell cycle progression and induces apoptosis. However, it also exhibits oncogenic activity associated with various processes, including invasion, inflammation and angiogenesis, which are essential in tumor development (8).

Plants are a major source of active substances that are used in therapeutic medicine as their metabolites have great 
structural diversity (9). Anti-inflammatory compounds have been extracted from natural products, including fruits, vegetables, spices and traditional medicinal herbs, and these compounds have been gaining importance as potential chemopreventive or therapeutic agents for cancer (10). In the last 2 decades, herbal products have been important candidates in the discovery of novel drugs for cancer (11). Drugs derived from natural products that have antibacterial, anticoagulant, antiparasitic, immunosuppressive and anticancer properties are able to treat $87 \%$ of categorized human diseases (12). There were 12 natural products and 32 derivatives of natural products among the 128 anticancer drugs released to the market between 1981 and 2010. They were obtained from various sources, including plants and microorganisms. Between 1940 and 2010, 175 small molecules were released for the treatment of cancer and of those, 131 molecules were developed from natural products (13). The investigation of novel plants with anti-inflammatory, anti-tumor and anti-carcinogenic potential is important and may enable the development of novel drugs for cancer treatment. Several members of Myrtaceae family have been previously investigated and various activities were observed, including antioxidant (14), anti-tumor (15-21) and anti-inflammatory activities (22-27). To the best of our knowledge, there are no existing studies investigating the activity of Calyptranthes grandifolia. However, important activities have been demonstrated in other members of the Calyptranthes genus (28-35). Thus, this genus demonstrates potential and may be beneficial in the treatment of inflammatory and tumor processes. The objective of the present study was to investigate the expression of genes associated with proliferation and inflammation in cells of the Caco- 2 cell line treated with extracts from Calyptranthes grandifolia O.Berg.

\section{Materials and methods}

Plant material. Leaves of Calyptranthes grandifolia O.Berg were collected in Lajeado, Rio Grande do Sul, in Southern Brazil and identified by Professor Elisete Maria de Freitas. From this material ethanol and hexane extracts were isolated according to the following methodology.

Hexanic extract preparation. The leaves of the plant were dried in an incubator with circulating air at $38^{\circ} \mathrm{C}$ for $24 \mathrm{~h}$. Subsequently, leaves were reduced to small fragments to increase the contact surface with the extraction solution. The leaves of Calyptranthes grandifolia O.Berg were packed with hexane solvent in an amber bottle at room temperature for $72 \mathrm{~h}$. Vacuum filtration was performed and the filtrate was stored in an amber jar at room temperature until the solvent was removed. Maceration of the leaves occurred for 2 weeks and the solvent was changed twice. Subsequently, vacuum filtration and removal of solvent was performed with the aid of a rotary evaporator at $40^{\circ} \mathrm{C}$. Finally, the extract obtained was stored in amber bottles and refrigerated at $4 \pm 1^{\circ} \mathrm{C}$ until experiments were performed.

Ethanolic extract preparation. Plant leaves were dried in an oven with circulating air at $38^{\circ} \mathrm{C}$ for $24 \mathrm{~h}$. Following this period, cold static soaking was performed on fragments of leaves with $90 \%$ ethanol and the material was placed in an amber bottle and kept at room temperature for 7 days. Subsequent to the extraction period, vacuum filtration and removal of solvent was performed with the aid of a rotary evaporator at $40^{\circ} \mathrm{C}$. The extract was placed in amber bottles and refrigerated at $4 \pm 1^{\circ} \mathrm{C}$ until experiments were performed.

Dilution of extracts. Solubilization of the extract was performed with dimethylsulfoxide (DMSO) so that the final concentration was $\leq 0.5 \%$.

Cell culture. Caco-2 colorectal adenocarcinoma cell line (HTB-37; American Type Culture Collection, Manassas, VA, USA) and RAW 264.7 murine macrophage cell line (TIB-71; American Type Culture Collection) were cultivated in microwell plates $\left(1 \times 10^{5}\right.$ cells/well) in an incubator $\left(37^{\circ} \mathrm{C}, 5 \% \mathrm{CO}_{2}\right)$. Subsequently, treatment with plant extract was performed at different concentrations $(25,50,100$ and $200 \mu \mathrm{g} / \mathrm{ml}$ ), with incubation in culture medium Dulbecco's modified Eagle's medium (DMEM, Sigma-Aldrich; Merck KGaA, Darmstadt, Germany) supplemented with $10 \%$ fetal bovine serum (FBS, Sigma-Aldrich; Merck KGaA) for $1 \mathrm{~h}$ at $37^{\circ} \mathrm{C}$. Subsequently, lipopolysaccharides (LPS; $1 \mu \mathrm{g} / \mathrm{ml}$ ) were added, and incubation was performed at $37^{\circ} \mathrm{C}$ and $5 \%$ $\mathrm{CO}_{2}$ for $24 \mathrm{~h}$ (36). Subsequent to $24 \mathrm{~h}$ incubation at different concentrations and treatments, extraction of total RNA was performed on the Caco- 2 cell line and the supernatant of RAW 264.7 cells was collected for ELISA assay. In addition to treatment with extracts, each culture plate had a positive control, in which cells were stimulated with LPS only, and a negative control with no stimulation or treatment. A total of 5 different experiments were performed for gene expression analysis.

Cell viability assay by alamar Blue ${ }^{\circledR}$. Caco-2 cells were plated at density of $1 \times 10^{5}$ cells $/ \mathrm{ml}$ in 96 -well plates containing $200 \mu \mathrm{l}$ of DMEM low glucose and $10 \%$ FBS, and incubated for $24 \mathrm{~h}$ in an atmosphere of $5 \% \mathrm{CO}_{2}, 90 \%$ humidity and $37^{\circ} \mathrm{C}$. Subsequently, cells were treated with concentrations of 25,50 , 100 or $200 \mu \mathrm{g} / \mathrm{ml}$ per well of extract, and incubated for $72 \mathrm{~h}$. Following this period, treatment was removed and a solution of $10 \%$ alamar Blue ${ }^{\circledR}$ dye was added per well. The absorbance readings were performed following $6 \mathrm{~h}$ incubation at $37^{\circ} \mathrm{C}$, at a wavelength of $540 \mathrm{~nm}$ (oxidized) and $620 \mathrm{~nm}$ (reduced) in an ELISA reader. As a negative control, cells were placed only in culture medium and DMSO. The percentage of cell viability was calculated using the following formula: $\%$ alamar Blue ${ }^{\circledR}$ reduction $=$ absorbance at $540 \mathrm{~nm}$-(absorbance at $630 \mathrm{~nm}$ x correction factor) $\mathrm{x} 100$. Correction factor was calculated by staining the culture medium with no cells.

Cell viability assay by Trypan Blue. Cells were removed from the plates with the aid of a scraper and transferred to $15 \mathrm{ml}$ centrifuge tubes $\left(1 \times 10^{5}\right.$ cells/centrifuge tube; Corning Incorporated, Corning, NY, USA), which were centrifuged at $600 \times \mathrm{g}$ for $10 \mathrm{~min}$ at room temperature. Following centrifugation, the supernatant was discarded and the pellet was resuspended in $1 \mathrm{ml}$ DMEM in a 1:10 dilution with Trypan Blue dye, which stains non-viable cells. Finally, a total count of viable cells was performed in a Neubauer chamber for subsequent plating of viable Caco-2 and RAW264.7 cells (37). 
RNA extraction. Total RNA extraction was performed by the TRIzol ${ }^{\circledR}$ method (Invitrogen; Thermo Fisher Scientific, Inc.) according to the manufacturer's instructions and purification was performed by illustra RNAspin Mini kit (GE Healthcare Life Sciences, Chalfont, UK). Total RNA was quantified using aL-Quant ${ }^{\circledR}$ spectrophotometer (Loccus, São Paulo, Brazil) with a $2 \mu \mathrm{l}$ final product of RNA extraction, and absorbance was read at $260 \mathrm{~nm}$.

Complementary DNA (cDNA) synthesis. Synthesis of cDNA was performed from $0.5 \mu \mathrm{g}$ total RNA, using poly-A tail complementary oligonucleotide primers and the Superscript ${ }^{\mathrm{TM}}$ II Reverse Transcriptase kit according to the manufacturer's protocol (Invitrogen; Thermo Fisher Scientific, Inc.). To each sample tube, $1 \mu \mathrm{l}$ of dNTP mix and $1 \mu \mathrm{l}$ OligodT was added prior to incubation for $5 \mathrm{~min}$ at $65^{\circ} \mathrm{C}$. Then, $9 \mu 1$ of a mix containing 10X PCR Buffer, $25 \mathrm{mM} \mathrm{MgCl}_{2}, 0.1 \mathrm{M}$ DTT and RNase OUT was added and further incubated for $2 \mathrm{~min}$ at $42^{\circ} \mathrm{C}$. A total of $1 \mu \mathrm{l}$ of Superscript II RT was added and incubated again at $42^{\circ} \mathrm{C}$ for $50 \mathrm{~min}$ and $70^{\circ} \mathrm{C}$ for $15 \mathrm{~min}$. Finally, $1 \mu \mathrm{l}$ of RNase $\mathrm{H}$ was added and incubated at $37^{\circ} \mathrm{C}$ for $20 \mathrm{~min}$. At the end of synthesis, the cDNA was stored at $-20^{\circ} \mathrm{C}$ until amplification was performed by quantitative polymerase chain reaction ( $\mathrm{PPCR})$.

$q P C R$. Gene expression analysis was performed by qPCR. The results were normalized to $\beta$-actin $(38,39)$ and the efficiency of reactions was evaluated using the standard curve of each gene analyzed. The qPCR results were expressed as the relative quantification of amplified cDNA with respect to the normalizer gene (40). Primers used for amplification of specific cDNA fragments were selected from the published sequence of each gene using online tool Primer3 v.0.4.0 (41). All primers were synthesized by Invitrogen (Thermo Fisher Scientific, Inc.; Table I). DNA amplification and relative quantification was performed using a StepOnePlus ${ }^{\mathrm{TM}}$ Real-Time PCR system (Applied Biosystems; Thermo Fisher Scientific, Inc.) and the Platinum ${ }^{\circledR}$ SYBR ${ }^{\circledR}$ Green qPCR SuperMix-UDG kit (Invitrogen; Thermo Fisher Scientific, Inc.) in a total volume of $25 \mathrm{ml}$ [12.5 $\mu \mathrm{l}$ SuperMix, $0.5 \mu \mathrm{l}$ (50 $\mu \mathrm{mol} / \mathrm{l})$ Rox reference dye, $0.3 \mu \mathrm{l}$ of each primer $(10 \mu \mathrm{mol} / 1$ forward and $10 \mu \mathrm{mol} / 1$ reverse), $9.4 \mu 1 \mathrm{H}_{2} \mathrm{O}$ and $2.0 \mu \mathrm{l} 1: 20$ diluted template cDNA] according to the manufacturer's (SYBR ${ }^{\circledR}$ Green kit) instructions. Amplification and reading of samples was performed in duplicate with the following protocol for all genes: Initial incubation for $3 \mathrm{~min}$ at $94^{\circ} \mathrm{C}$; followed by 45 cycles of $30 \mathrm{sec}$ denaturation at $94^{\circ} \mathrm{C} ; 30 \mathrm{sec}$ annealing at $55^{\circ} \mathrm{C}$ and $30 \mathrm{sec}$ extension at $60^{\circ} \mathrm{C}$. To confirm specificity of the reaction, a dissociation curve was performed for each primer pair with melting temperature analysis of each gene.

TNF- $\alpha$ cytokine release in RAW 264.7 cells by ELISA assay. Following $24 \mathrm{~h}$ incubation of RAW 264.7 cells with LPS stimulation, $0.4 \mathrm{ml}$ supernatant was collected and stored at $-80^{\circ} \mathrm{C}$ and used for quantification of the release of TNF- $\alpha$ pro-inflammatory cytokine using the Mouse TNF alpha ELISA Ready-SET-Go ${ }^{\circledR}$ ELISA kit (cat. no. 88-7324-86; e-Bioscience, Inc., San Diego, CA, USA) according to the manufacturer's instructions.
Table I. Oligonucleotide primers for quantitative polymerase chain reaction.

\begin{tabular}{lcc}
\hline Gene & Sequence (5'-3') & $\begin{array}{c}\text { Fragment } \\
\text { size }(\mathrm{bp})\end{array}$ \\
\hline $\begin{array}{l}\text { NF- } \kappa \mathrm{B} \\
\text { Sense }\end{array}$ & ACACCGTGTAAACCAAAGCC & 209 \\
Antisense CAGCCAGTGTTGTGATTGCT & \\
p38 $\alpha$ & & 243 \\
Sense & CAGTGGGATGCATAATGGCC & \\
Antisense & GCATCTTCTCCAGCAAGTCG & \\
TNF- $\alpha$ & & 120 \\
Sense & CCCTGGTATGAGCCCATCTATC & \\
Antisense AAAGTAGACCTGCCCAGACTCG & \\
$\beta$-actin & \multicolumn{2}{c}{140} \\
Sense & CTGGAACGGTGAAGGTGACA & \\
Antisense AAGGGACTTCCTGTAACAATGCA & \\
\hline
\end{tabular}

$\mathrm{NF}-\kappa \mathrm{B}$, nuclear factor $\kappa \mathrm{B} ; \mathrm{p} 38 \alpha, \mathrm{p} 38 \alpha$ mitogen-activated protein kinase; TNF- $\alpha$, tumor necrosis factor- $\alpha$.

Statistical analysis. Data were tabulated and analyzed with descriptive statistics using SPSS software (version 20.0; IBM SPSS, Armonk, NY, USA) and GraphPad Prism (version 5.0; GraphPad Software, Inc., La Jolla, CA, USA). Comparison between the controls was performed using an unpaired Student's $t$-test and the effects of extracts were analyzed by one-way analysis of variance followed by the Tukey test. $\mathrm{P}<0.05$ was considered to indicate a statistically significant difference.

\section{Results}

Cell viability by alamar Blue ${ }^{\circledR}$. It was observed that the ethanolic and hexane extracts of Calyptranthes grandifolia O.Berg did not affect the cell proliferation when compared with the negative control. The negative control exhibited a viability of $62.6 \%( \pm 4.367)$, and for ethanolic and hexane extracts at tested concentrations, the percentages of viability were similar to the control (Fig. 1).

Gene expression analysis. For the analysis of the genes of interest, the positive control consisted of Caco- 2 cells that were stimulated only by LPS with no extract treatment, and the negative control consisted only of cells in culture. The comparison between negative and positive controls was performed in order to verify whether there was a difference in gene expression when stimulated by LPS. Increased expression of TNF- $\alpha$ was observed following treatment with LPS compared with the negative control, however, this was not significantly different. In addition, the expression of NF- $\kappa \mathrm{B}$ and $\mathrm{p} 38 \alpha$ were similar in negative and positive control groups; expression was not altered by LPS treatment. Thus, the expression of these genes was stable in the negative and positive control groups (Fig. 2). When evaluating the effect of the ethanolic extract of Calyptranthes grandifolia on gene expression, a decrease 


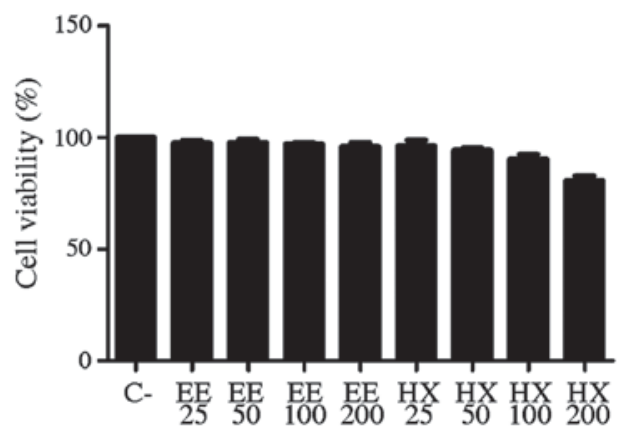

Figure 1. Percentage cell viability by alamar Blue ${ }^{\circledR}$ method. Results were analyzed by one-way analysis of variance followed by Tukey test $(\mathrm{P}=0.775 ; \mathrm{n}=3)$. $\mathrm{C}$-, negative control; EE, ethanolic extract; HX, hexanic extract.

in TNF- $\alpha$ expression was observed, which was significant at concentrations of 100 and $200 \mu \mathrm{g} / \mathrm{ml}$, compared with the positive control $(\mathrm{P}<0.025$; Fig. $3 \mathrm{~A})$. Regarding NF- $\kappa \mathrm{B}$ gene expression, expression was similar for all treatments and there were no significant changes (Fig. 3B). The expression of $\mathrm{p} 38 \alpha$ increased with increasing concentrations of ethanolic extract, however, these increases were not significant (Fig. 3C). The expression of TNF- $\alpha, N F-\kappa B$ and $\mathrm{p} 38 \alpha$ with hexane extract treatment exhibited no significant variation compared with the positive control (Fig. 3D-F).

TNF- $\alpha$ cytokine release in RAW 264.7 cells by ELISA. In order to demonstrate the decrease in TNF- $\alpha$ in gene expression, an ELISA colorimetric assay was performed to evaluate the level of cytokine release. A macrophage lineage was used, characterized by the release of inflammatory cytokines. The inhibition of TNF- $\alpha$ was significant $(\mathrm{P}<0.05)$ with the ethanolic extract at a concentration of $200 \mu \mathrm{g} / \mathrm{ml}(464.0 \pm 36.7 \mathrm{pg} / \mathrm{ml})$ compared with the positive control (1143.0 $\pm 118.0 \mathrm{pg} / \mathrm{ml}$; Fig. 4) and also when compared with a concentration of $25 \mu \mathrm{g} / \mathrm{ml}(1272 \pm 293 \mathrm{pg} / \mathrm{ml})$. Concentrations of $25 \mu \mathrm{g} / \mathrm{ml}(1272 \pm 293 \mathrm{pg} / \mathrm{ml}), 50 \mu \mathrm{g} / \mathrm{ml}$ $(1179 \pm 261 \mathrm{pg} / \mathrm{ml})$ and $100 \mu \mathrm{g} / \mathrm{ml}(1185 \pm 312 \mathrm{pg} / \mathrm{ml})$ exhibited no significant difference compared with the positive control (Fig. 4). The negative control $(53.6 \pm 36.8 \mathrm{pg} / \mathrm{ml})$ exhibited a significant difference in TNF- $\alpha$ cytokine release compared with the positive control $(\mathrm{P}<0.0001$; Fig. 4) and compared with concentrations of 25,50 and $100 \mu \mathrm{g} / \mathrm{ml}(\mathrm{P}<0.001$; Fig. 4). There were no significant differences when treated with hexanic extract (data not shown).

\section{Discussion}

Stimulation by LPS increased TNF- $\alpha$ gene expression in the positive control (stimulated with LPS) compared with the negative control (no stimulation with LPS). The expression of $\mathrm{p} 38 \alpha$ and NF- $\mathrm{\kappa B}$ did not change in the positive control compared with the negative control. Herath et al (42) demonstrated that different serotypes of LPS produce different responses upon cell stimulation. For example, in human gingival fibroblasts there was no activation of the NF- $\mathrm{kB}$ pathway by LPS $1435 / 1449$. However, LPS1690 significantly activated the pathway. Other pro-inflammatory genes also exhibit modified activation by different LPS serotypes.
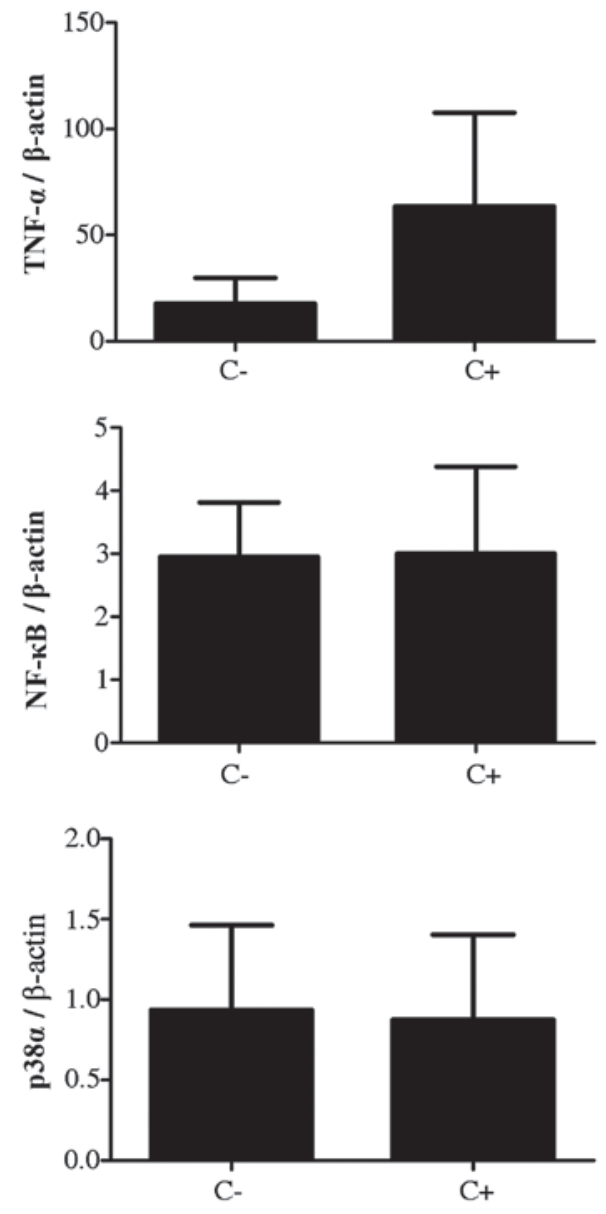

Figure 2. Effect of LPS on gene expression compared with the negative control. Results were analyzed by an unpaired Student's $t$ test and are presented as the mean \pm standard error of the mean $(n=5)$. P-values for TNF- $\alpha, N F-\kappa B$ and $\mathrm{p} 38 \alpha$ are $\mathrm{P}=0.337, \mathrm{P}=0.97$ and $\mathrm{P}=0.937$, respectively. LPS, lipopolysaccharide; TNF- $\alpha$, tumor necrosis factor- $\alpha$; NF- $\kappa B$, nuclear factor- $\mathrm{kB}$; $\mathrm{p} 38 \alpha, \mathrm{p} 38 \alpha$ mitogen-activated protein kinase; $\mathrm{C}-$, negative control; $\mathrm{C}+$, positive control.

When evaluating the effect of Calyptranthes grandifolia O.Berg extract treatment, on TNF- $\alpha$ gene expression, the present study observed reduced expression compared with the positive control at certain concentrations in both extracts. However, only the ethanolic extract at concentrations of 100 and $200 \mu \mathrm{g} / \mathrm{ml}$ significantly reduced TNF- $\alpha$ expression compared with the positive control. To the best of our knowledge, there are no previous studies that have evaluated the effect of this plant on TNF- $\alpha$ expression, however, Ferreira et al (43) evaluated the anti-inflammatory activity of Campomanesia adamantium extracts (also a member of the Myrtaceae family) and the production of nitric oxide (NO), TNF- $\alpha$ and IL-10 in J774.A1 macrophages stimulated with LPS/interferon- $\gamma$. Paw edema in mice was inhibited by oral administration of the extracts, it inhibited $\mathrm{NO}$ and TNF- $\alpha$ production, and increased IL-10 production. Thus, the anti-inflammatory activity of the extract may be associated with the inhibition of pro-inflammatory cytokines and increased IL-10. Li et al (44) evaluated the activity of flavonoids in RAW 264.7 cells and demonstrated the inhibition of NO, TNF- $\alpha$, IL- 6 and IL-Ip, indicating an important role for flavanoids in anti-inflammatory activity (44). 

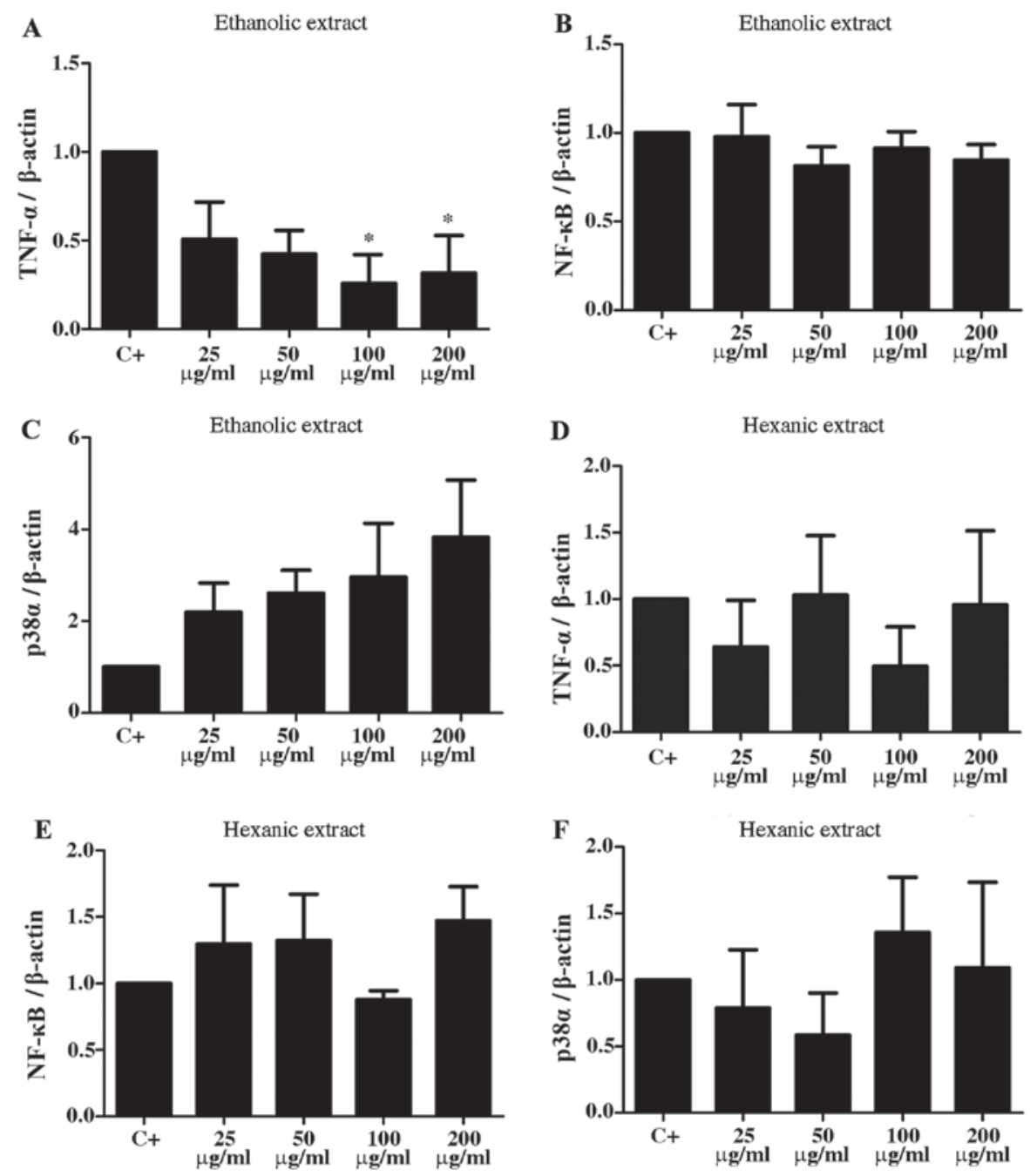

Figure 3. Representative plots of the effect of various concentrations of ethanolic and hexane extracts on the gene expression of TNF- $\alpha$, NF- $\mathrm{kB}$ and $\mathrm{p} 38 \alpha$ compared with the positive control. Effect of ethanolic extract on the gene expression of (A) TNF- $\alpha$, (B) NF- $\mathrm{kB}$ and (C) p38 $\alpha$. Effect of hexanic extract on the gene expression of (D) TNF- $\alpha$, (E) NF- $\mathrm{kB}$ and (F) p38 $\alpha$. Data are presented as the mean + standard error of the mean, $n=5$. ${ }^{*} \mathrm{P}<0.025$ vs. C+. TNF- $\alpha$, tumor necrosis factor- $\alpha$; NF- $\kappa \mathrm{B}$, nuclear factor- $\mathrm{\kappa} \mathrm{B} ; \mathrm{p} 38 \alpha, \mathrm{p} 38 \alpha$ mitogen-activated protein kinase; $\mathrm{C}+$, positive control.

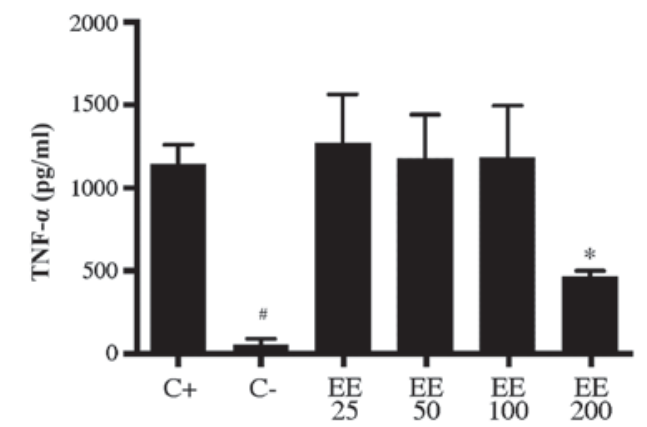

Figure 4. Evaluation of the inhibition of TNF- $\alpha$ cytokine release following treatment with ethanolic extract in RAW264.7 cells stimulated with lipopolysaccharides. Data are presented as the mean \pm standard error of the mean with 3 replicates. ${ }^{*} \mathrm{P}<0.05$ and ${ }^{\#} \mathrm{P}<0.01$ vs. $\mathrm{C}+\mathrm{TNF}-\alpha$, tumor necrosis factor- $\alpha$; + , positive control; $\mathrm{C}$-, negative control; $\mathrm{EE}$, ethanolic extract.

The present study observed no changes in NF- $\mathrm{BB}$ expression between the different extracts and concentrations tested. The activation of NF- $\mathrm{KB}$ in Caco- 2 cells may be associated with the state of cell differentiation. NF- $\mathrm{BB}$ signaling pathways or IкB kinase do not exist in isolation, therefore, various mechanisms integrate their activity with other signaling pathways (45). NF- $\mathrm{KB}$ is a protein that modulates the apoptotic response as it is a transcription factor that protects against and contributes to apoptosis (46). The nuclear factor is a central regulator of immune responses and has an important role in the expression of cytokine genes, including IL-2, IL-6, C-C motif chemokine 2 and CD40 ligand. Furthermore, it is also involved in the expression of genes associated with cell survival and proliferation, including cyclin D1, cyclin D2, c-Myc, c-Myb, cyclooxygenase-2, Bcl-2 and Bcl-xl (47,48). Thus, NF- $\mathrm{KB}$ is considered as a tumor promoter and is frequently identified as constitutively active in tumors (49-52). NF- $\mathrm{kB}$ may not have been activated due to the high expression of TNF- $\alpha$, and thus by anti-inflammatory signals.

The present study observed no significant differences in p38 $\alpha$ gene expression between the various treatments and concentrations. However, its expression did increase with increasing concentrations of ethanolic extract, with the highest expression at a concentration of $200 \mu \mathrm{g} / \mathrm{ml}$. The activation of p38 isoforms is specifically controlled by different regulators and they are co-activated by several combinations $(53,54)$. The 
p38 $\alpha$ MAPK activates other kinases and therefore regulates diverse cellular responses. Thus, p38 signaling may be associated with inflammation, the cell cycle, cell death, development, differentiation, senescence and tumorigenesis (55). The anti-tumor effect of various chemotherapeutic drugs is based on apoptosis through p38 $\alpha$ activation. However, it is important to note that this kinase is associated with various responses, and may also be involved in resistance to chemotherapy in certain types of tumors (56). Campbell et al (57) demonstrated that a modification of $\mathrm{p} 38 \alpha$ MAPK inhibited TNF- $\alpha$ production in macrophages induced by LPS, post-transcriptionally. Furthermore, p38 negatively regulated the expression of $\mathrm{NF}-\kappa \mathrm{B}$, which allows transcriptional control of TNF- $\alpha$ as the nuclear factor is required for its expression (57). Despite the pro-apoptotic role of p38 $\alpha, \mathrm{p} 38 \alpha$ MAPK has also been previously associated with an anti-apoptotic activity (58-61). Comes et al (62) demonstrated that p38 $\alpha$ induced the survival of colorectal cancer cells by inhibiting autophagy. Another mechanism involved in $\mathrm{p} 38 \alpha$-induced survival is the activation of the activating transcription factor $6 \alpha$-Ras homolog enriched in brain-mechanistic target of rapamycin (ATF6 $\alpha$-Rheb-mTOR) pathway, which promoted the survival of dormant tumor cells in vivo (63). Although the present study observed no significant differences in the mRNA levels of $\mathrm{p} 38 \alpha$ and $\mathrm{NF}-\kappa \mathrm{B}$, further studies are required with larger sample sizes, as well as studies that investigate the expression at the protein level, to verify the presence and activation of these proteins. The increase in mRNA levels is not directly proportional to the amount of protein translated, due to transcriptional and post-translational modifications.

The extracts included in the present study did not affect the cell viability when compared with the negative control. According to the US National Cancer Institute, an extract may be considered active or cytotoxic when it presents cytotoxicity with $\mathrm{IC}_{50}$ values $<30 \mu \mathrm{g} / \mathrm{ml}$ (half maximal inhibitory concentration) (64). In this aspect, cytotoxic extracts maybe potential candidates for anti-carcinogenic studies (65). However, it is important to note that these statements should be tested in other cell lines in order to observe potential selective cytotoxicity.

The antioxidant activity was also determined in ethanolic and hexane extracts of Calyptranthes grandifolia by the research group (data not shown). This activity was evaluated by antioxidant activity testing, by capturing the free radical 2,2-diphenyl-1-picryl-hidrazila (66). The results demonstrated that the hexane extract exhibited no antioxidant activity, however, the ethanolic extract exhibited a dose dependent antioxidant activity. The observed antioxidant activity may be associated with a potential anti-inflammatory activity of the extract, based on the results observed for gene expression and TNF- $\alpha$ cytokine release. The ethanolic extract had significant antioxidant activity compared with hexane, which corresponds with the decrease of TNF- $\alpha$ gene expression.

Based on the significant reduction of TNF- $\alpha$ when Caco-2 cells were treated with the ethanolic extract of Calyptranthes grandifolia O.Berg, the significant inhibition of TNF- $\alpha$ cytokine release in RAW 264.7 murine macrophages, antioxidant activity of the extract and the lack of effects on cell viability, it is indicated that this extract may have anti-inflammatory potential. However, further studies are required to elucidate the signaling pathway that may be activated. Given the variation between experiments and potential post-transcriptional regulation, the analysis of other genes is required in order to assess the potential pathways implicated. Furthermore, it is important to analyze protein expression in order to confirm that the expressed genes in Caco- 2 cells are translated and determine the respective levels of translation.

In conclusion, Calyptranthes grandifolia ethanolic extract at concentrations of 100 and $200 \mu \mathrm{g} / \mathrm{ml}$ significantly reduced TNF- $\alpha$ gene expression in the Caco- 2 cell line. There were no significant differences in $\mathrm{p} 38 \alpha$ and NF- $\mathrm{kB}$ gene expression. Cells treated with hexane extract exhibited no significant variations in the expression of the genes investigated at any of the concentrations. Ethanolic extract at $200 \mu \mathrm{g} / \mathrm{ml}$ significantly inhibited TNF- $\alpha$ pro-inflammatory cytokine release. The extracts were not considered to be cytotoxic and are not candidates for anti-carcinogenic studies in this lineage. However, other studies using different cell lines maybe performed to identify selective cytotoxicity. The results of the present study indicate that ethanolic extract has an anti-inflammatory potential by decreasing expression of TNF- $\alpha$. Thus, it is important to investigate its genotoxicity and to conduct in vivo analysis to confirm its anti-inflammatory potential.

\section{References}

1. Germano G, Allavena P and Mantovani A: Cytokines as key component of cancer-related inflammation. Cytokine 43: 374-379, 2008.

2. Bartlett DL, Ma G, Alexander HR, Libutti SK and Fraker DL: Isolated limb reperfusion with tumor necrosis factor and melphalan in patients with extremity melanoma after failure of isolated limb perfusion with chemotherapeutics. Cancer 80: 2084-2090, 1997.

3. Madhusudan S, Muthuramalingam SR, Braybrooke JP, Wilner S, Kaur K, Han C, Hoare S, Balkwill F and Ganesan TS: Study of etanercept, a tumor necrosis factor-alpha inhibitor, in recurrent ovarian cancer. J ClinOncol 23: 5950-5959, 2005.

4. Harrison ML, Obermueller E, Maisey NR, Hoare S, Edmonds K, Li NF, Chao D, Hall K, Lee C, Timotheadou E, et al: Tumor necrosis factor alpha as a new target for renal cell carcinoma: Two sequential phase II trials of infliximab at standard and high dose. J ClinOncol 25: 4542-4549, 2007.

5. Garg A and Aggarwal BB: Nuclear transcription factor-kappaB as a target for cancer drug development. Leukemia 16: 1053-1068, 2002.

6. Beg AA and Baltimore D: An essential role for NF-kappaB in preventing TNF-alpha-induced cell death. Science 274: 782-784, 1996.

7. Stroh C, Held J, Samraj AK and Schulze-Osthoff K: Specific inhibition of transcription factor NF-kappaB through intracellular protein delivery of IkappaBalpha by the Herpes virus protein VP22. Oncogene 22: 5367-5373, 2003.

8. Dolado I and Nebreda AR: Regulation of tumorigenesis by $\mathrm{p} 38 \alpha$ MAP kinase. Topics Curr Genet 20: 99-128, 2008.

9. Brandão HN, David JP, Couto RD, Nascimento JAP and David JM: Química e farmacologia de quimioterápicos antineoplásicos derivados de plantas. Quím Nova 33: 1359-1369, 2010.

10. Aravindaram K and Yang NS: Anti-inflammatory plant natural products for cancer therapy. Planta Med 76: 1103-1117, 2010.

11. Bhanot A, Sharma R and Noolvi MN: Natural sources as potential anti-cancer agents: A review. Int J Phytomed 3: 9-26, 2011.

12. Newman DJ, Cragg GM and Snader KM: The influence of natural products upon drug discovery. Nat Prod Rep 17: 215-234, 2000.

13. Newman DJ and Cragg GM: Natural products as sources of new drugs over the 30 years from 1981 to 2010. J Nat Prod 75: 311-335, 2012. 
14. Souza-Moreira TM, Moreira RRD, Sacramento LVS and Pietro RCLR: Histochemical, phytochemical and biological screening of Pliniacauliflora (Mart.) Kausel (Myrtaceae) leaves. RevBras Farmacogn 20: 48-53, 2010.

15. Zhang P, Zhang E, Xiao M, Chen C and Xu W: Enhanced chemical and biological activities of a newly biosynthesized eugenol glycoconjugate, eugenol $\alpha$-D-glucopyranoside. Appl Microbiol Biotechnol 97: 1043-1050, 2013.

16. Rizzo LY, Longato GB, Ruiz AL, Tinti SV, Possenti A, Vendramini-Costa DB, Sartoratto A, Figueira GM, Silva FL, Eberlin MN, et al: In vitro, in vivo and in silico analysis of the anticancer and estrogen-like activity of guava leaf extracts. Curr Med Chem 21: 2322-2330, 2014

17. Sultana B, Anwar F, Mushtaq M, Aslam M and Ijaz S: In vitro antimutagenic, antioxidant activities and total phenolics of clove (Syzygiumaromaticum L.) seed extracts. Pak J Pharm Sci 27: 893-899, 2014

18. Liu H, Schmitz JC, Wei J, Cao S, Beumer JH, Strychor S, Cheng L, Liu M, Wang C, Wu N, et al: Clove extract inhibits tumor growth and promotes cell cycle arrest and apoptosis. Oncol Res 21: 247-259, 2014

19. Ye CL, Liu Y and Wei DZ: Antioxidant and anticancer activity of 3'-formyl-4',6'-dihydroxy-2'-methoxy-5'-methylchalcone and (2S)-8-formyl-5-hydroxy-7-methoxy-6-methylflavanone. J Pharm Pharmacol 59: 553-559, 2007.

20. Aisha AF, Ismail Z, Abu-Salah KM, Siddiqui JM, Ghafar G and Abdul Majid AM: Syzygium campanulatum korth methanolic extract inhibits angiogenesis and tumor growth in nude mice. BMC Complement Altern Med 13: 168, 2013

21. Pascoal AC, Ehrenfried CA, Lopez BG, de Araujo TM Pascoal VD, Gilioli R, Ruiz AL, Carvalho JE, Stefanello ME and Salvador MJ: Antiproliferative activity and induction of apoptosis IN PC-3 cells by the chalcone cardamonin from Campomanesia adamantium (Myrtaceae) in a bioactivity-guided study. Molecules 19: 1843-1855, 2014.

22. Michel MCP, Guimarães AG, Paula CA, Rezende SA, Sobral MEG and Guimarães DAS: Extracts from the leaves of Campomanesia velutina inhibits production of LPS/INF- $\gamma$ induced inflammatory mediators in J774A.1 cells and exerts anti-inflammatory and antinociceptive effects in vivo. Rev Bras Farmacogn 23: 927-936, 2013

23. Jeong D, Yang WS, Yang Y, Nam G, Kim JH, Yoon DH, Noh HJ, Lee S, Kim TW, Sung GH and Cho JY: In vitro and in vivo anti-inflammatory effect of Rhodomyrtus tomentosa methanol extract. J Ethnopharmacol 146: 205-213, 2013.

24. Flores G, Dastmalchi K, Wu SB, Whalen K, Dabo AJ, Reynertson KA, Foronjy RF, D Armiento JM and Kennelly EJ: Phenolic-rich extract from the Costa Rican guava (Psidiumfriedrichsthalianum) pulp with antioxidant and anti-inflammatory activity. Potential for COPD therapy. Food Chem 141: 889-895, 2013.

25. Serafino A, Sinibaldi Vallebona P, Andreola F, Zonfrillo M, Mercuri L, Federici M, Rasi G, Garaci E and Pierimarchi P: Stimulatory effect of Eucalyptus essential oil on innate cell-mediated immune response. BMC Immunol 9, 2008.

26. Santos FA, Rao VSN and Silveira ER: Anti-inflammatory and analgesic activities of the essential oil of Psidium guianense. Fitoterapia 68: 65-68, 1997.

27. Sharma R, Kishore N, Hussein A and Lall N: Antibacterial and anti-inflammatory effects of Syzygiumjambos L. (Alston) and isolated compounds on acne vulgaris. BMC Complement Altern Med 13: 292, 2013.

28. Gourdeau H, Leblond L, Hamelin B, Desputeau C, Dong K, Kianicka I, Custeau D, Boudreau C, Geerts L, Cai SX, et al: Antivascular and antitumor evaluation of 2-amino-4-(3-bromo-4,5-dimethoxy-phenyl)-3-cyano-4H-chro menes, a novel series of anticancer agents. Mol Cancer Ther 3 : 1375-1384, 2004.

29. Chetan BS, Nimesh MS, Manish PP and Ranjan GP: Microwave assisted synthesis of novel $4 \mathrm{H}$-chromene derivatives bearing phenoxypyrazole and their antimicrobial activity assess. J Serb ChemSoc 77: 1165-1174, 2012.

30. Mladenović M, Mihailović M, Bogojević D, Matić S, Nićiforović N, Mihailović V, Vuković N, Sukdolak S and Solujić S: In vitro antioxidant of selected 4-Hydroxy-chromene-2-one derivatives-SAR, QSAR and DFT studies. Int J MolSci 12 2822-2841, 2011.

31. Cheng JF, Ishikawa A, Ono Y, Arrhenius T and Nadzan A: Novel chromene derivatives as TNF-alpha inhibitors. Bioorg Med Chem Lett 13: 3647-3650, 2003.
32. Thareja S, Verma A, Kalra A, Gosain S, Rewatkar PV and Kokil GR: Novel chromeneimidazole derivatives as antifungal compounds: Synthesis and in vitro evaluation. Acta Pol Pharm 67: 423-427, 2010

33. Correa RGC, Silva ML, Maia JGS, Gottlieb OR, Mourão JC, Marx MC, Morais AA, Moura LL and Magalhães MT: Acta Amaz 2: 53, 1972.

34. Silva ML, Luz AIR, Zoghbi MGB, Ramos LS and Maia JGS Essential oil variation in Calyptranthes spruceana. Phytochem 23: 2515-2516, 1984

35. Maia JGS, Zoghbi MGB and Andrade EHA: Aromatic Plants in the Amazon and their Essential Oils. Emílio Goeldi Paraense Museum (Adolpho Ducke Series): Belém, 2001 (Portuguese).

36. Nanthakumar NN, Fusunyan RD, Sanderson I and Walker WA: Inflammation in the developing human intestine: A possible pathophysiologic contribution to necrotizing enterocolitis. Proc Natl Acad Sci USA 97: 6043-6048, 2000

37. Strober W: Trypan blue exclusion test of cell viability. Curr Protoc Immunol, 2001.

38. Yang J, Yang Q, Yu S and Zhang X: Evaluation and validation of suitable reference genes for reverse transcription-quantitative polymerase chain reaction studies in cholangiocarcinoma patients and cell lines. Oncol Lett 11: 2673-2681, 2016.

39. Piana C, Wirth M, Gerbes S, Viernstein H, Gabor F and Toegel S: Validation of reference genes for qPCR studies on Caco-2 cell differentiation. Eur J Pharm Biopharm 69: 1187-1192, 2008.

40. Livak KJ and Schmittgen TD: Analysis of relative gene expression data using real-time quantitative PCR and the 2(-Delta Delta C(T)) method. Methods 25: 402-408, 2001

41. Rozen S and Skaletsky H: Primer3 on the WWW for general users and for biologist programmers. Methods Mol Biol 132: 365-386, 2000.

42. Herath TD, Darveau RP, Seneviratne CJ, Wang CY, Wang Y and Jin L: Tetra- and penta-acylated lipid A structures of Porphyromonasgingivalis LPS differentially activate TLR4-mediated NF- $\kappa \mathrm{B}$ signal transduction cascade and immuno-inflammatory response in human gingival fibroblasts. PLoS One 8: e58496, 2013.

43. Ferreira LC, Grabe-guimarães A, de Paula CA, Michel MC, Guimarães RG, Rezende SA, de Souza Filho JD and Saúde-Guimarães DA: Anti-inflammatory and antinociceptive activities of Campomanesia adamantium. J Ethnopharmacol 9: 100-108, 2013.

44. Li LJ, Yu LJ, Li YC, Liu MY and Wu ZZ: In vitro anti-inflammatory and free radical scavenging activities of flavans from Ilex centrochinensis. Zhongguo Zhong Yao Za Zhi 40: 1523-1528, 2015 (In Chinese).

45. Perkins ND: Integrating cell-signalling pathways with NF-kappaB and IKK function. Nat Rev Mol Cell Biol 8: 49-62, 2007.

46. Foo SY and Nolan GP: NF-kappaB to the rescue: RELs, apoptosis and cellular transformation. Trends Genet 15: 229-235, 1999.

47. Clément JF, Meloche S and Servant MJ: The IKK-related kinases: From innate immunity to oncogenesis. Cell Res 18: 889-899, 2008

48. Vallabhapurapu S and Karin M: Regulation and function of NF-kappaB transcription factors in the immune system. Annu Rev Immunol 27: 693-733, 2009.

49. Pikarsky E, Porat RM, Stein I, Abramovitch R, Amit S, Kasem S, Gutkovich-Pyest E, Urieli-Shoval S, Galun E and Ben-Neriah Y: NF-kappaB functions as a tumour promoter in inflammation-associated cancer. Nature 23: 461-466, 2004.

50. Wolska A, Lech-Maranda E and Robak T: Toll-like receptors and their role in hematologic malignancies. CurrMol Med 9: 324-335, 2009.

51. Surh YJ: Cancer chemoprevention with dietary phytochemicals. Nat Rev Cancer 3: 768-780, 2003.

52. Aggarwal BB and Shishodia S: Molecular targets of dietary agents for prevention and therapy of cancer. Biochem Pharmacol 71: 1397-1421, 2006

53. Hu MC, Wang YP, Mikhail A, Qiu WR and Tan TH: Murine p38-delta mitogen activated protein kinase, a developmentally regulated protein kinase that is activated by stress and proinflammatory cytokines. J BiolChem 274: 7095-7102, 1999.

54. Enslen H, Raingeaud J and Davis RJ: Selective activation of p38 mitogen-activated protein (MAP) kinase isoforms by the MAP kinase kinases MKK3 and MKK6. J BiolChem 273: 1741-1748, 1998.

55. Zarubin T and Han J: Activation and signaling of the p38 MAP kinase pathway. Cell Res 15: 11-18, 2005. 
56. Porras A and Guerrero C: Role of $\mathrm{p} 38 \alpha$ in apoptosis: Implication in cancer development and therapy. Atlas Genet Cytogenet Oncol Haematol 15: 316-326, 2011.

57. Campbell J, Ciesielski CJ, Hunt AE, Horwood NJ, Beech JT, Hayes LA, Denys A, Feldmann M, Brennan FM and Foxwell BM: A novel mechanism for TNF- $\alpha$ regulation by $\mathrm{p} 38$ MAPK: Involvement of NF-kappaB with implications for therapy in rheumatoid arthritis. J Immunol 173: 6928-6937, 2004.

58. Héron-Milhavet L and Leroith D: Insulin-like growth factor I induces MDM2-dependent degradation of $\mathrm{p} 53$ via the $\mathrm{p} 38$ MAPK pathway in response to DNA damage. J BiolChem 3: 15600-15606, 2002.

59. Okamoto S, Krainc D, Sherman K and Lipton SA: Antiapoptotic role of the p38 mitogen-activated protein kinase-myocyte enhancer factor 2 transcription factor pathway during neuronal differentiation. Proc Natl AcadSci USA 20: 7561-7566, 2000.

60. Park JM, Greten FR, Li ZW and Karin M: Macrophage apoptosis by anthrax lethal factor through p38 MAP kinase inhibition. Science 20: 2048-2051, 2002.

61. Zhang X, Shan P, Alam J, Davis RJ, Flavell RA and Lee PJ: Carbon monoxide modulates Fas/Fas ligand, caspases, and Bcl-2 family proteins via the p38alpha mitogen-activated protein kinase pathway during ischemia-reperfusion lung injury. J BiolChem 13: 22061-22070, 2003.
62. Comes F, Matrone A, Lastella P, Nico B, Susca FC, Bagnulo R, Ingravallo G, Modica S, Lo Sasso G, Moschetta A, et al: A novel cell type-specific role of p38alpha in the control of autophagy and cell death in colorectal cancer cells. Cell Death Differ 14: 693-702, 2007.

63. Schewe DM and Aguirre-Ghiso JA: ATF6alpha-Rheb-mTOR signaling promotes survival of dormant tumor cells in vivo. Proc Natl Acad Sci USA 29: 10519-10524, 2008

64. Geran RI, Greenberg NH, McDonald MM, Schumacher AM and Abott BJ: Protocols for screening chemical agents and natural products against animal tumour and other biological systems. Cancer Chemother Rep 3: 17-19, 1972.

65. Suffness M and Pezzuto JM: Assays related to cancer drug discovery. In: Hostettmann K (ed), Methods in Plant Biochemistry. Assays for Bioactivity 6: 71-133, 1990.

66. Mensor LL, Menezes FS, Leitão GG, Reis AS, Santos TC, Coube CS and Leitão SG: Screening of Brazilian plant extracts for antioxidant activity by the use of DPPH free radical method. Phytother Res 15:127-130, 2001. 